\title{
CONGENITAL AORTIC VALVULAR STENOSIS
}

BY

\author{
MAURICE CAMPBELL AND RALPH KAUNTZE
}

From the Cardiac Department, Guy's Hospital, and the Institute of Cardiology

Received August 4, 1952

The frequency with which the diagnosis of aortic stenosis is missed has been increasingly realized during the last 25 years. When a rough systolic is heard at the base of the heart a special effort should be made to feel a thrill, and if these two signs are present the diagnosis of aortic stenosis must be considered. The presence or absence of peripheral signs in the pulse is merely a measure of the severity of the stenosis; this principle is more widely recognized when there is an aortic diastolic murmur and aortic regurgitation, and may or may not be a water-hammer pulse and a wide pulse pressure.

Etiologically, there is an even greater neglect of a possible congenital origin. We think that congenital aortic stenosis is relatively common but is often missed because so many years may pass before there are significant symptoms, and in a patient of forty or so, the lesion is looked on as calcific or atheromatous when these changes are simple additions to the congenital lesion. This assessment is of more than academic interest, bearing both on prognosis and the consideration of surgical relief.

In this paper we wish to describe 40 cases of aortic stenosis that are, we think, congenital. About half of these were sent up ostensibly as congenital heart disease for a more detailed diagnosis, but nearly half were seen in routine cardiological practice and the possibility of the lesion being congenital had rarely been entertained.

The earliest description of aortic valvular stenosis is probably that of Carolus Rayger (1672), recorded by Bonetus (1679) in his "Sepulchretum," under the heading " de morte repentina." The observation was in a middle-aged Parisian cobbler who dropped dead in the street, and at necropsy showed aortic valves of "bone." Chevers (1842) recorded one variety in which the mouth of the aorfa was contracted from birth, its valves being blended with each other so as to present a mere funnel-shaped tube with a slit at the apex.

Although the bulbus cordis forms a functionally important part of the outflow tract of the right ventricle, it is as a rule completely incorporated into the outflow tract of the left ventricle; if involution is incomplete a remnant persists in the form of a ridge or diaphragm containing elastic tissue, between the ventricular chamber and the aortic valves (Keith, 1924). Subaortic stenosis is understandable embryologically and is comparable with pulmonary infundibular stenosis, but the origin of aortic valvular stenosis is less obvious. The valves originate from division of the four bulbar cushions and faulty division may result in bicuspid valves. Koletsky (1941) refers to two types of this abnormality-one with two cusps that appear normal, and the other with one of the cusps divided by a narrow ridge of elastic tissue extending into the sinus in the long axis of the aorta. Where fusion and thickening of the aortic valves are present at birth, "fœtal endocarditis" has sometimes been invoked, and Brown (1950) inclines to this view. There are, however, many arguments against it, especially the resemblance to pulmonary valvular stenosis and the association with other congenital lesions, for example, the cases of Smart (1904) and Shennan (1905) with both valvular and subvalvular stenosis, and two of our own cases with dextrocardia. 
Whatever the cause may be, the deformity progresses with the deposition of platelet thrombi and calcium until the original structure is buried in the calcified fibroid plaques, and the natural bias is to accept an acquired rheumatic ætiology. It is difficult to explain the rarity of calcification in stenosis of the pulmonary valve, whereas that of the aortic valve may be remarkably extensive (Fig. 1), unless perhaps patients with severe pulmonary stenosis do not live long enough.

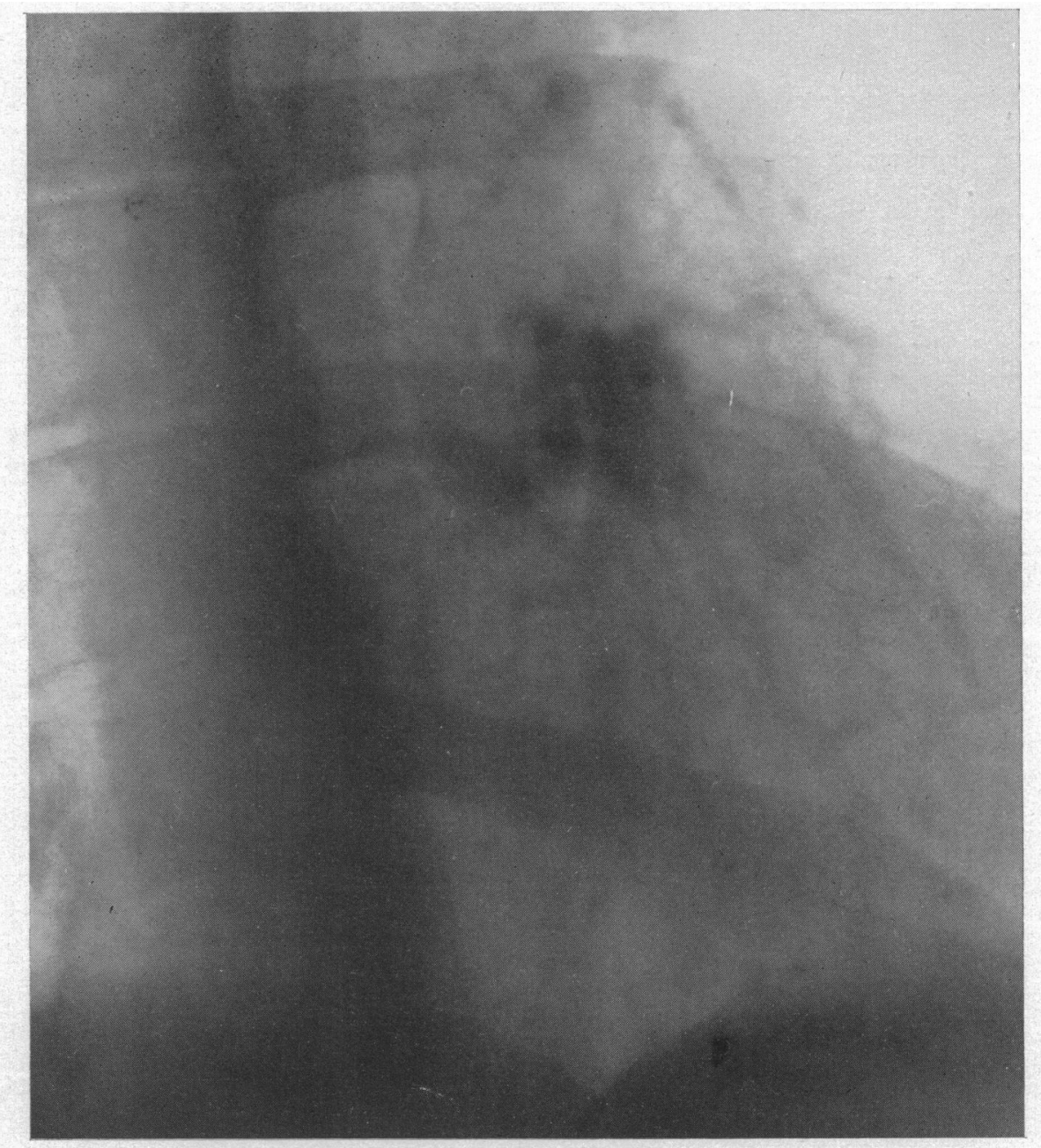

FIG. 1.-Extensive calcification of the aortic valves and surrounding area from a young man, aged 18, with congenital aortic stenosis. Right anterior oblique view. Case 26. His sudden death after this paper was completed confirmed the diagnosis and the gross calcification.

\section{Clinical Findings}

The table (see p. 187), with the patients arranged according to the age at which the murmur was first heard, gives some details of the findings. The physique of these patients is in the main outstandingly good as in many of those with coarctation of the aorta, and the delicate-looking gracile type is unusual. The sex incidence is striking, for there are no less than 31 males (77\%). Karsner and Koletsky (1947), in reviewing aortic stenosis confirmed by necropsy, give the corrected incidence as three men to two women. In the present group there is no question of heavy manual 
labour being a factor, for most of the hearts were recognized as abnormal before this could have been operative. The ages range from 3 to 50 years.

Age when Murmur was first Heard. This is important because the diagnosis of heart disease soon after birth is one of the best reasons for accepting it as congenital. There were 20 patients where the murmur was heard or the diagnosis was made in early childhood, sometimes in the first few months of life and generally before they were three years old, but twice in the fourth and twice in the fifth year. Most of these are still under ten, but there are two in their teens and six, five of whom are women, who are in good health at $24,25,34,37,38$, and 38 years. Incidentally, two of the latter have recently been through a pregnancy without difficulty.

The development of a rheumatic valvular lesion before the age of three or four is so uncommon that it seems certain that these patients have congenital heart disease or, if not, are suffering from some infection that is not recognized as a cause of valvular disease.

There were another 17 patients, eight under 19 and nine between 23 and 50 years of age, where the murmur was heard later than this but while they were still children. It was heard before they were 11 in twelve, between 12 and 15 in three, and between 18 and 19 in two. The fifteen adults in these two groups are specially interesting when considering the prognosis of congenital aortic stenosis. There seems little doubt about most of these 37 , but we are including three others (Cases 38, 39, and 40), as examples of older cases that are usually diagnosed as calcific aortic stenosis and not recognized as congenital. In these three-all men between 40 and 42 -the murmur had only been heard a few years before, and sometimes it seemed that it should have been heard earlier at army examination or elsewhere if it had been present. It is possible that they have developed atherosclerosis on a valve that was normal, but they show no other evidence of this, and we think it more likely that aortic stenosis was present throughout life but gave rise to no symptoms until the development of sclerotic changes.

We have not included a doctor, aged 61, who has had a successful valvotomy for severe aortic stenosis, which may have been congenital as he had had a murmur and thrill, a low blood pressure, and a tendency to faintness for 35 years. As there was severe aortic stenosis without regurgitation or any evidence of mitral stenosis or much enlargement of the heart, it seems unlikely that it was rheumatic.

There was a history of rheumatic fever in two patients and a doubtful history in three more, but except in one (Case 28) this was later than the recognition of the murmur. None of them had any evidence of mitral stenosis, and the course in those who were observed for several years showed none of the special features of rheumatic heart disease.

The original diagnoses included ventricular septal defect in eight patients, congenital pulmonary stenosis in five, congenital aortic stenosis in four, patent ductus arteriosus in four, and rheumatic aortic incompetence in one.

Symptoms. The degree and onset of dyspnœa were variable; there were only nine patients in whom it was more than slight and then usually after the age of 30 years. Case 12 had in fact attended hospital at 16 years of age, as he wished to take part in cross-country running and 100-mile bicycle races, by neither of which he was unduly inconvenienced: his cardiogram (Fig. 2) showed gross left ventricular strain; but at the age of five it had shown some right axis deviation in the standard leads.

There were 11 instances of angina of effort, usually starting in the late teens; but none where it was present at rest. Eight patients complained of dizziness with effort, and more rarely of syncope: in three of these there was not concurrent angina of effort. About half these patients had a low pulse pressure around $20 \mathrm{~mm}$. $\mathbf{H g}$, but it was equally small in as many of the others. Syncopal attacks with effort occurred in Case 7 when her hæmoglobin was 40 per cent, but were absent when it had risen to 80 per cent.

Signs. The pulse was often small and the pulse pressure was generally between $20-40$ (average $31 \mathrm{~mm}$. $\mathrm{Hg}$ ). It was at the low level of about 15-25 in seventeen patients and generally there was more depression of the systolic level than elevation of the diastolic level. The pulse was recorded 
as small in eight patients, as slow rising in five, as bisferiens in one, and as having some collapsing element in three, but even in these the pulse pressure was not wide. There is no reason for expecting a small pulse pressure in every case with aortic stenosis for the aortic orifice must be reduced to a quarter of its size before changes in the circulation can be demonstrated (Wiggers, 1935).

A left ventricular impulse was felt in half. It is notable that a systolic thrill was felt at some time in all patients, although its situation varied. In some it was palpable only above the sternal notch; in a child of three years (Case 8), it was felt at the apex only. The intensity of the thrill was

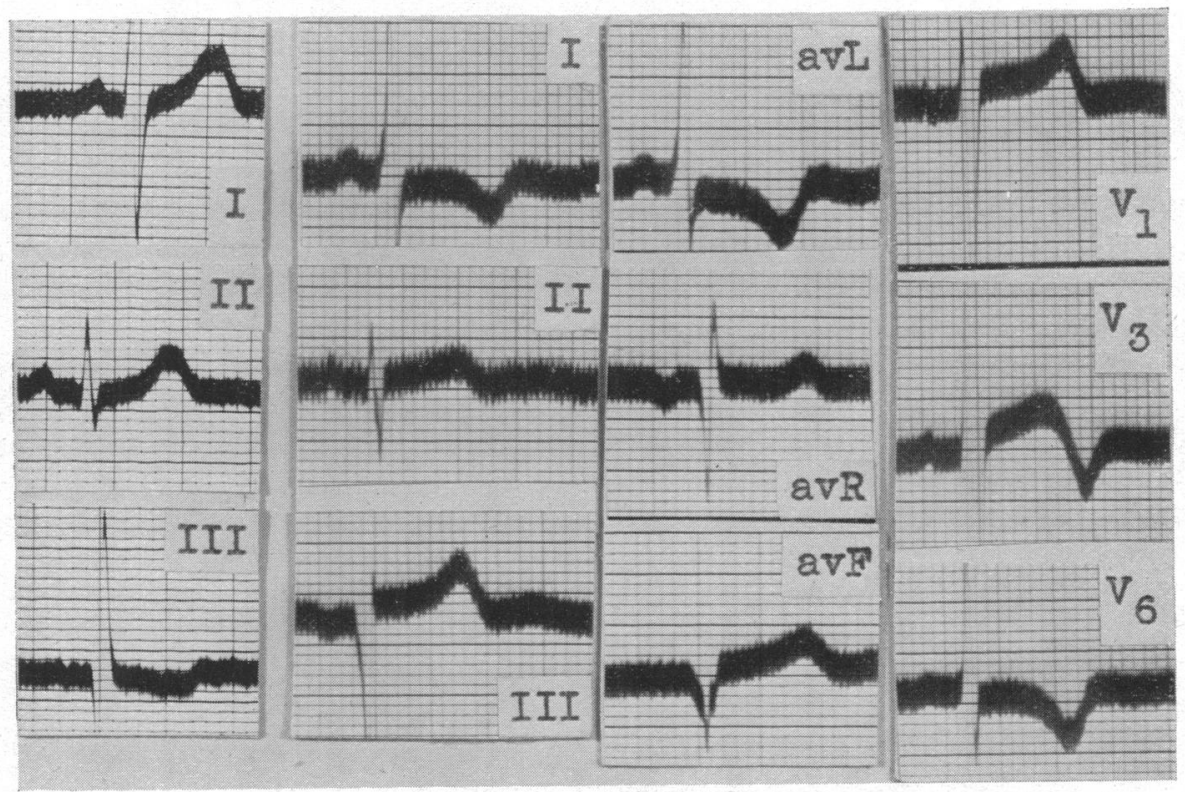

A

B

FIG. 2.-Electrocardiograms showing the development of left ventricular preponderance and strain. Case 12. (A) When aged 5, with some right axis deviation. (B) When aged 16, with left ventricular strain.

on occasion striking; in a girl, aged 8 (Case 22), it was felt through no less than 32 layers of thin blanket and in one woman (Case 18) its rasping quality interfered with sleep.

Systolic murmurs were invariably harsh, often conducted to the carotids, and heard principally at the base, but to this there were exceptions; in Case 35 , at the age of 15 , the murmur was found at the apex alone, but two years later it is well heard over the aortic area.

The aortic second sound was weak or absent in half the patients (19). In six of these the valves were seen to be calcified, but in the remainder with calcified valves the second sound was normal or even loud.

There were 18 patients with early diastolic murmurs, but in most of these it was a soft murmur that was not very easily heard, and there were only five in whom it was loud. The youngest was four (Case 3), yet in a number over 30 years of age diastolic murmurs were persistently absent (Case 37, aged 49). Case 9 apparently developed a diastolic murmur between four and six years of age.

In two instances (Cases 10 and 13) the heart lay mostly to the right of the midline.

Size and Shape of the Heart. Generally the heart was little enlarged, and this agrees with the classical view that aortic stenosis produces concentric hypertrophy, which is not easily seen, and that dilatation follows much later, if at all. In most of these patients the shape was normal or rather vertical, sometimes with obvious rounding of the left ventricle (Fig. 3-5); but in about one-sixth of 


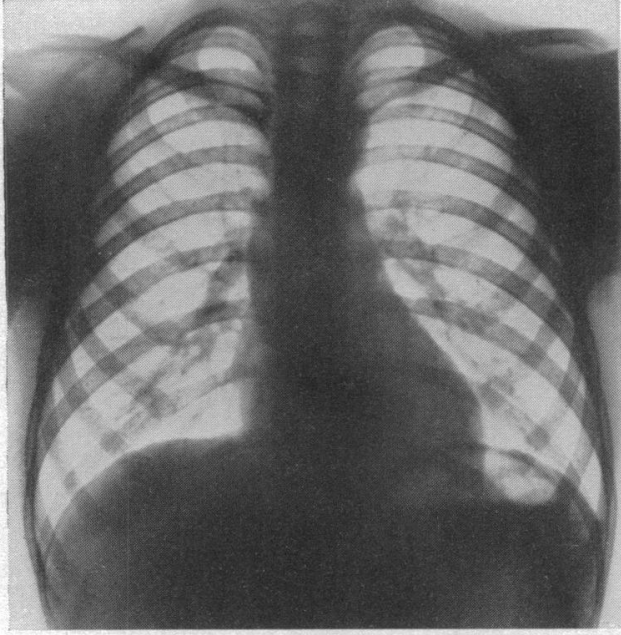

A

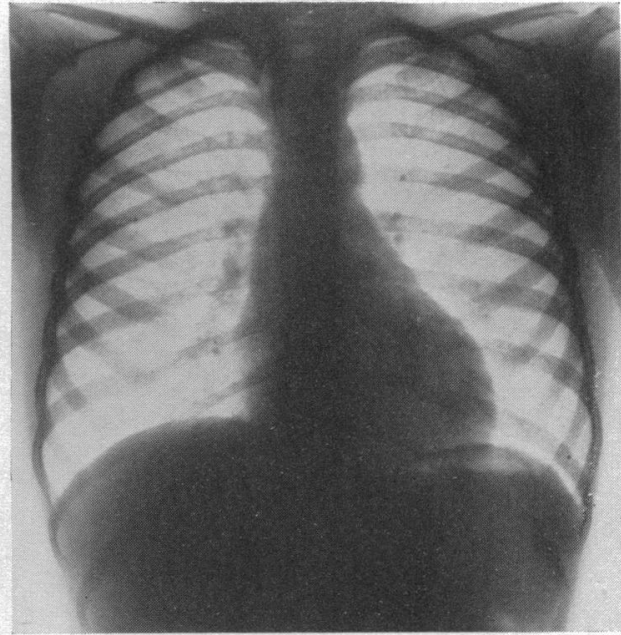

B

FIG. 3.-The heart in children with congenital aortic stenosis, showing prominence of the first part of the aorta, but less than in some children and most older patients. (A) A small heart (c.t.r. $46 \%$ ) from a boy, aged 12. Case 31. (B) A normal-sized heart (c.t.r. $50 \%$ ) from a boy, aged 9. Case 11.

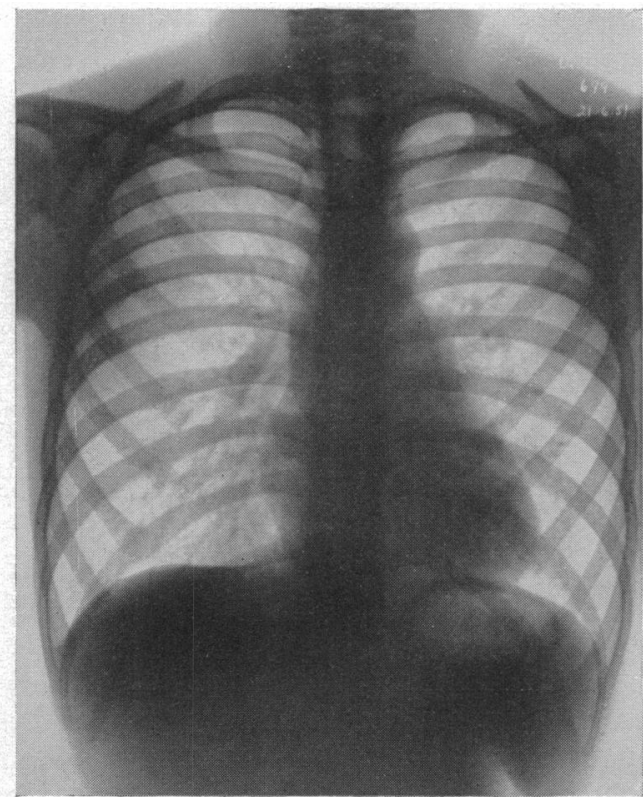

A

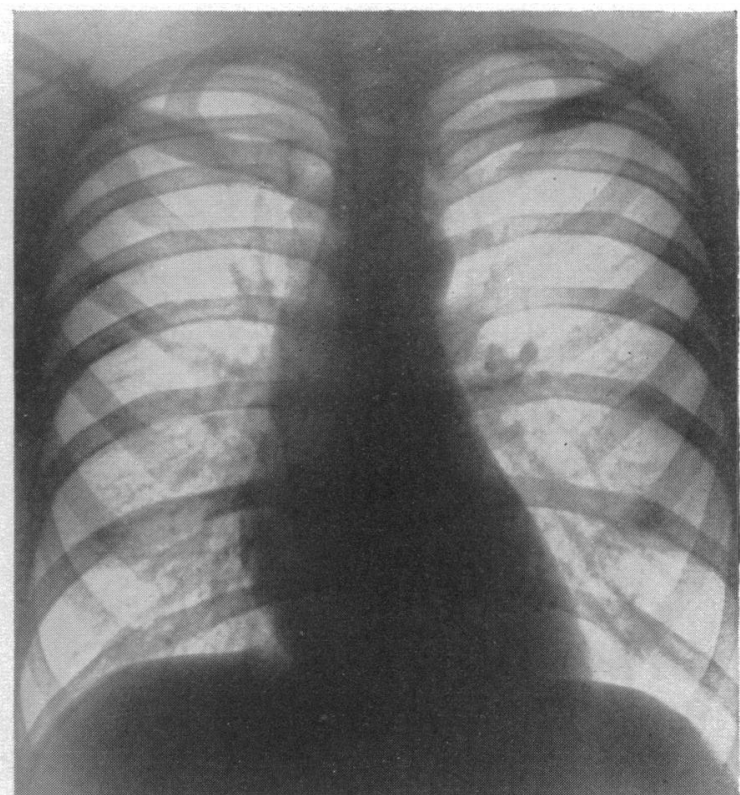

B

Fig. 4.-The heart in congenital aortic stenosis, showing typical dilatation of the first part of the aorta. (A) From a girl, aged 9 (c.t.r. 49\%). Case 21. (B) From a boy, aged 18 (c.t.r. 49\%). Case 24. 


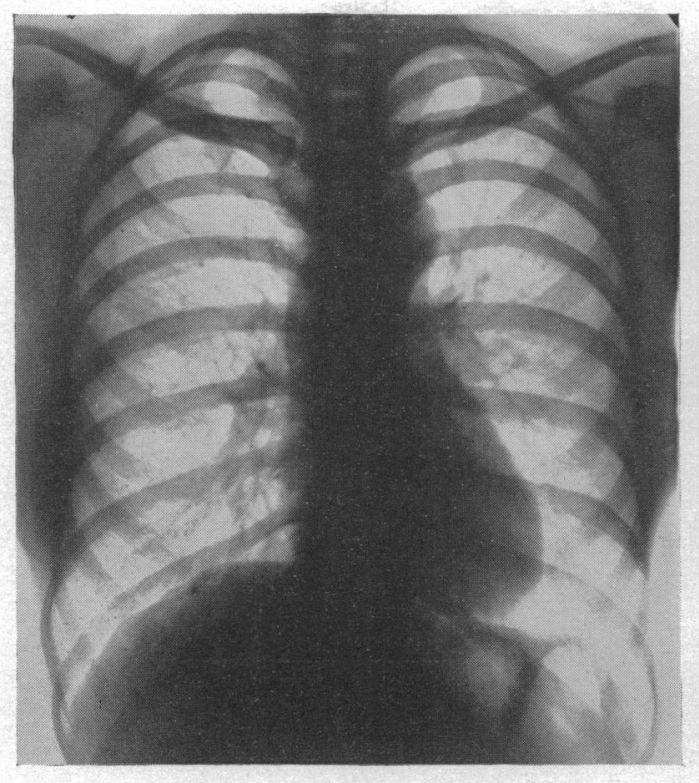

A

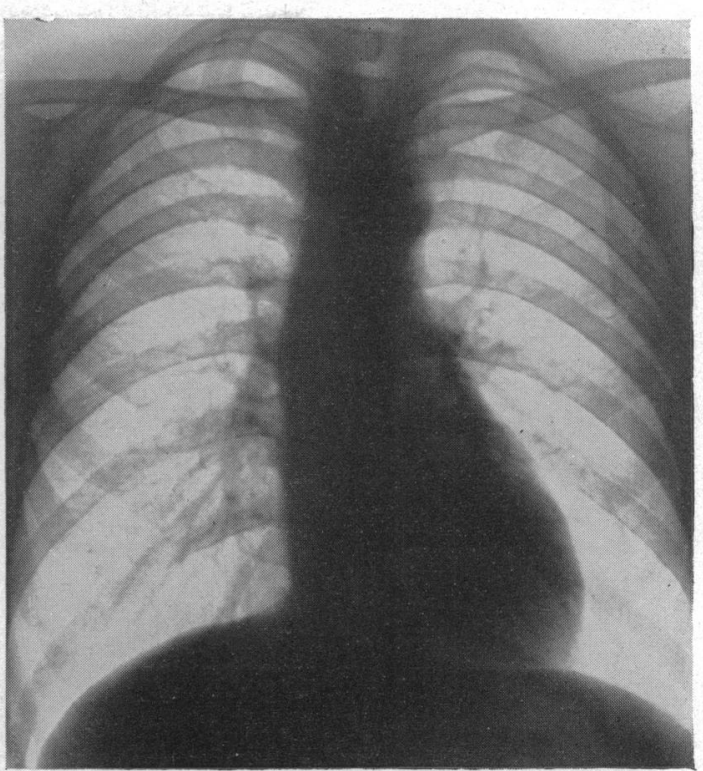

B

FIG. 5.- The heart in congenital aortic stenosis in adults, still without cardiac enlargement. (A) From a man, aged 26 (c.t.r. 45\%). Case 28. (B) From a woman, aged 37 (c.t.r. 46\%). Case 7.

them the heart was larger than this and showed some tendency to become horizontal, thus resembling more closely the characteristic picture of aortic disease with incompetence (Fig. 6B and 7A).

Even on the film the dilatation of the first part of the aorta was noticeable in two-thirds of the patients, but in the remaining third the aorta looked normal. There were only two older patients with the general dilatation that is so often seen with atheroma. The aortic knuckle was not specially prominent as it so often is with an atheromatous aorta: it looked normal in about two-thirds of our patients, and was less visible than usual in the other third.

The cardiothoracic ratio was between 45 and 52 in two-thirds, and between 54 and 56 per cent in one-third of the patients. Rather surprisingly, the heart is not necessarily larger in the older patients, though this must certainly happen sometimes. If our cases are divided into three groups according to age, the average ratio was only a fraction above 50 per cent in each. The characteristic outline is seen again and again and the figures shown could have been reproduced almost exactly from other cases.

On fluoroscopy some enlargement of the left ventricle was almost invariable, but it was gross in only three (Cases 3, 36, and 37), and in retrospect it seems likely that the first of these had a ruptured aneurysm of the aortic sinus. The most striking and constant finding was the enlargement of the first part of the aorta, well shown in most of the figures and best seen on fluoroscopy in the left anterior oblique position. Fig. 7B illustrates a gross example, in which dilatation was such as to cause an impulse and pain in the right chest anteriorly. This dilatation and the hyperdynamic appearance were commented upon in almost all those over the age of ten years: they were not always associated with a diastolic murmur and only in Case 29 with a wide pulse pressure.

The aortic valves were seen to be calcified in 11 patients, such calcification extending at times beyond the cusps. In 7 of these 11 an early diastolic murmur was heard. The youngest in whom calcification was seen was 18 years of age (Case 26), and he was the only one of the twenty-three patients under 24 in whom it was seen. On the other hand it was seen in ten of the seventeen over 24 years of age. No special methods were used to demonstrate it, e.g. tomography, which Davies and Steiner (1949) thought the most effective. It was, therefore, probably present more often than 


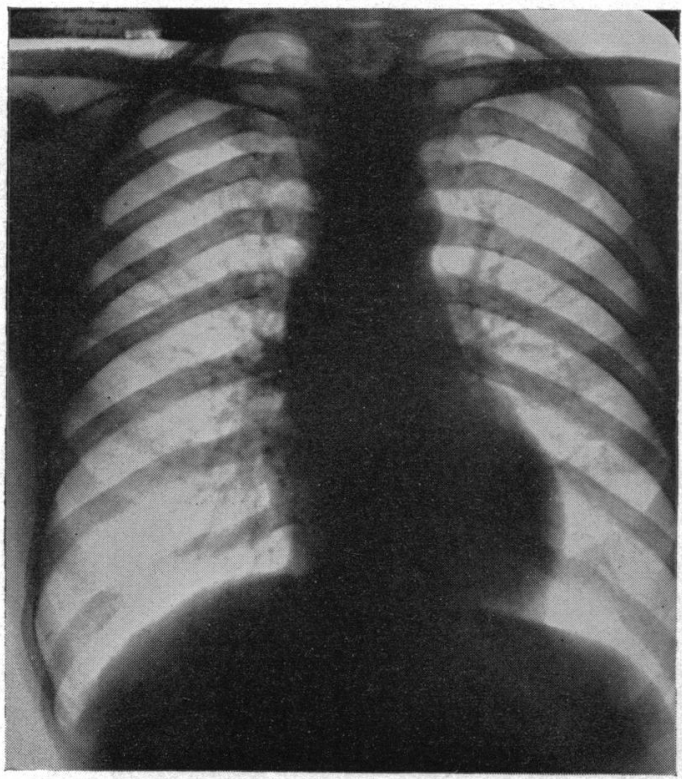

A

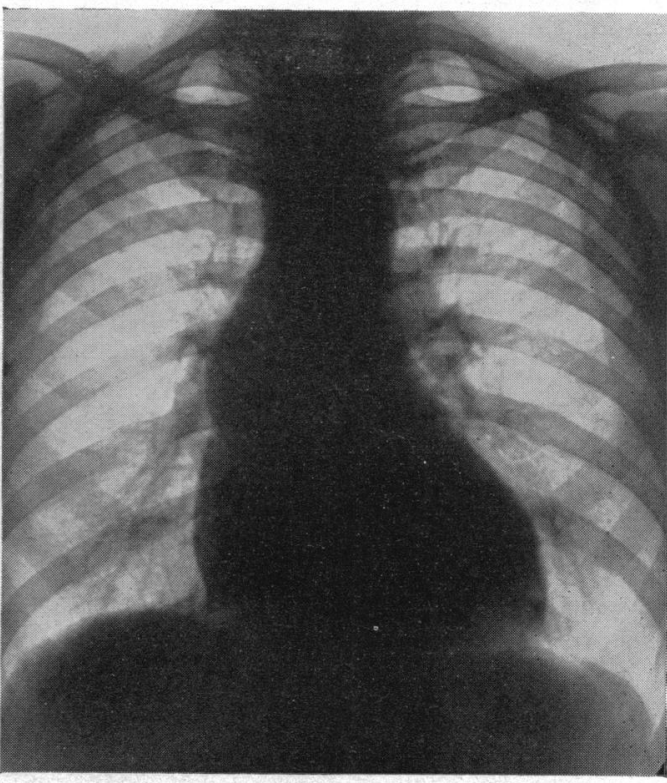

B

FIG. 6.-The heart in congenital aortic stenosis in adults, showing the same prominence of the aorta, and that the heart may or may not be enlarged. (A) From a man, aged 39, showing no cardiac enlargement (c.t.r. 45\%), though he had much anginal pain. Case 38. (B) With rather more prominence of the first part of the aorta, from a man, aged 49, with early heart failure (c.t.r. 53\%). Case 37.

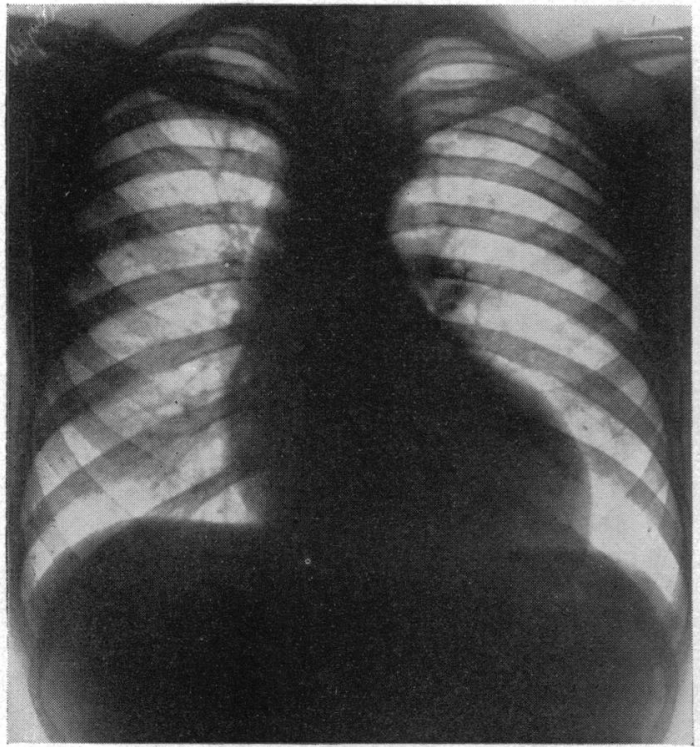

A

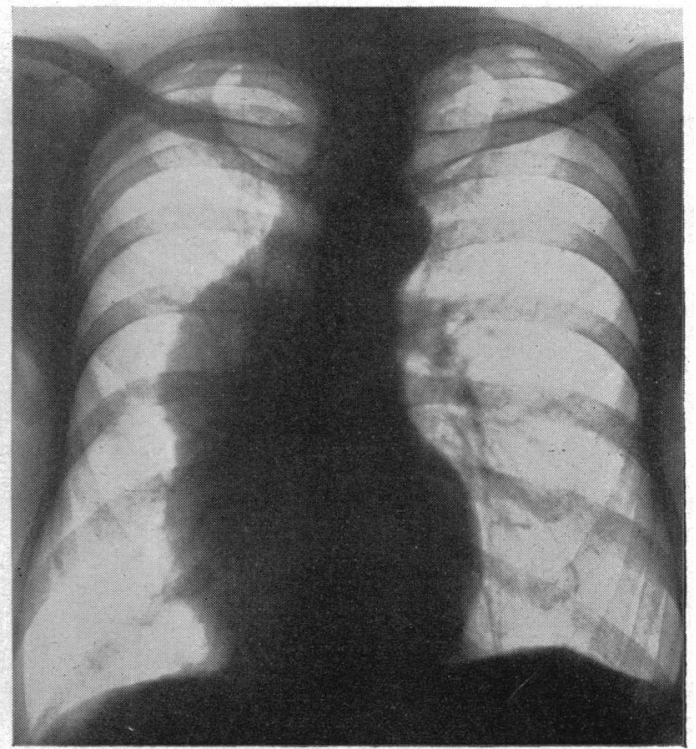

B

FIG. 7.-(A) One of the largest hearts (c.t.r. 56\%) seen in congenital aortic stenosis, looking more like the usual picture of left ventricular enlargement secondary to aortic incompetence. From a man, aged 28, who had developed aortic incompetence. Case 29. (B) The most extreme example of dilatation of the first part of the aorta, still without any enlargement of the heart (c.t.r. 45\%) from a man, aged 50. Case 25. 
it was detected and we think that few patients are without some calcification after 30 and very few after 40 years of age. Gibbs (1935), in 26 necropsies of cases of aortic stenosis found calcification common in the rheumatic and almost invariable in the atherosclerotic ones, sometimes as early as the fourth decade and commonly in the fifth decade.

Electrocardiograms. Left ventricular strain, namely, $\mathrm{S}-\mathrm{T}$ segment depression and $\mathrm{T}$ wave flattening or inversion over the left ventricle, was present in 22 of these cardiograms, occurring in patients as young as two years (Case 3) or, if he is excluded, six years (Case 9). Its development is illustrated in Fig. 2, 8, and 9 and the following history is given as an example.

Case 30. A boy of 12, without any significant symptoms, was referred because of a murmur that had been found when he had pneumonia two years before. There was a rough systolic murmur and thrill, maximum in the pulmonary area. The cardiogram was normal (Fig. 8A). The diagnosis made by one of us was congenital pulmonary stenosis.

When 28, he was working as a draughtsman and again attended hospital. There had been moderate dyspnœea and sub-sternal tightness on vigorous exertion since he was 16 , but walking had never been troublesome. He was hypersthenic. The systolic thrill was now felt best to the right of the midline and the murmur was heard over the whole præcordium, and louder to the right. On fluoroscopy the ascending aorta was unduly prominent and the left ventricle slightly enlarged. Calcification of the aortic valves was not on this occasion seen, but was evident a year later. The cardiogram was now that of left heart strain with a transverse electrical axis (Fig. 8B).

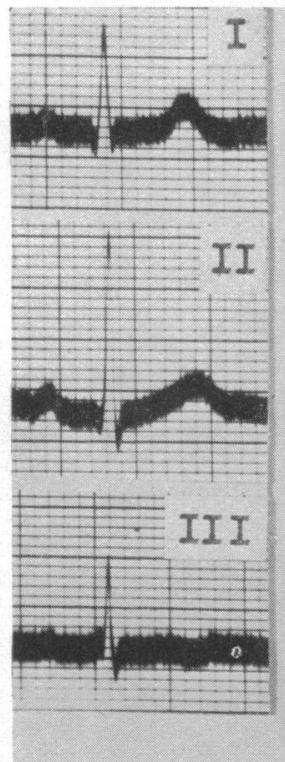

A

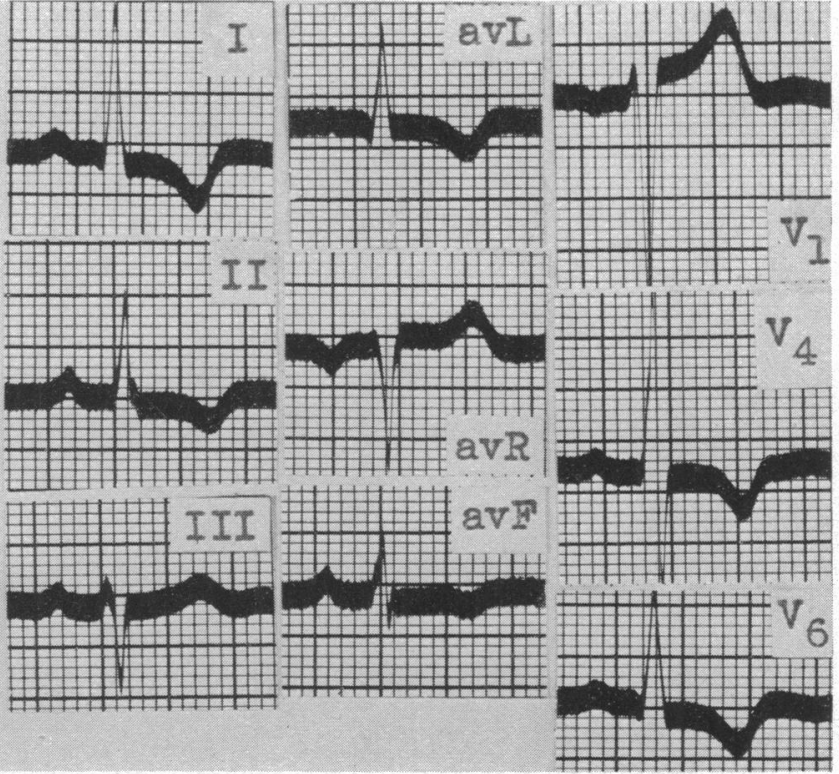

B

FiG. 8.- Electrocardiograms showing the development of left ventricular preponderance and strain. (A) When aged 12, with a normal cardiogram. (B) When aged 28, with left ventricular strain. Case 30 .

The combination of a vertical electrical axis with left heart strain was noted in nine instances (Fig. 10): there is no suggestion that in these the axis becomes transverse later. Kiloh (1950) drew attention to the vertical electrical axis in two of his cases with left ventricular strain (20 per cent of those studied cardiographically) but did not find left ventricular preponderance as often as we have. That the electrical axis should remain vertical when left heart strain is present might be attributed to the muscular hypertrophy being concentric, yet in seven of the nine patients a diastolic murmur was present and the aortic incompetence, even though trivial, may well have 
TABLE

Some Clinical Findings in our 40 Patients with Congenital Aortic Stenosis

\begin{tabular}{|c|c|c|c|c|c|c|c|c|c|c|c|c|c|c|c|c|c|}
\hline \multirow[b]{2}{*}{ U: } & \multirow[b]{2}{*}{ 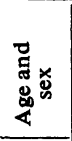 } & \multirow[b]{2}{*}{ 品莺 } & \multirow[b]{2}{*}{ 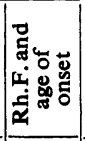 } & \multirow[b]{2}{*}{ 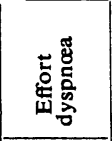 } & \multirow[b]{2}{*}{ 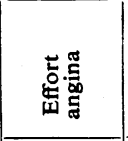 } & \multirow[b]{2}{*}{ 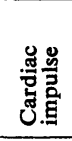 } & \multirow[b]{2}{*}{ 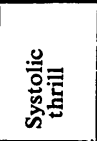 } & \multirow[b]{2}{*}{ 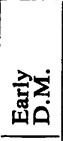 } & \multirow[b]{2}{*}{ Yุ } & \multirow[b]{2}{*}{ : } & \multirow[b]{2}{*}{ 莺 } & \multicolumn{3}{|c|}{ Aorta and valves } & \multirow[b]{2}{*}{ 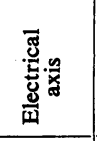 } & \multirow[b]{2}{*}{ 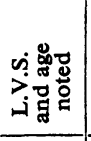 } & \multirow[b]{2}{*}{ 总 } \\
\hline & & & & & & & & & & & & 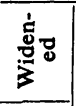 & 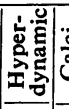 & 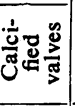 & & & \\
\hline$\frac{1}{2}$ & $\begin{array}{r}8 \mathrm{M} \\
25 \mathrm{~F}\end{array}$ & $\begin{array}{r}\text { Birth } \\
6 / 12\end{array}$ & $=$ & & Moderate & $\mathbf{N}$ & ++ & $\overline{+}$ & $=$ & $\begin{array}{l}105 / 75 \\
120 / 90\end{array}$ & $=$ & 二 & $\overline{+}$ & 二 & $\begin{array}{l}\text { Vertical } \\
\text { Vertical }\end{array}$ & $\overline{24}$ & $\mathrm{v}$ \\
\hline 3 & $4 \mathrm{~F}$ & $10 / 12$ & - & slight & - & LV & +++ & ++ & $(-)$ & $110 / 70$ & ++++ & + & + & - & $\begin{array}{c}\text { Trans- } \\
\text { verse }\end{array}$ & 2 & $\mathbf{v}$ \\
\hline $\begin{array}{l}4 \\
5\end{array}$ & $\begin{array}{r}3 \mathbf{M} \\
38 \\
\mathbf{M}\end{array}$ & $\begin{array}{l}11 / 12 \\
12 / 12\end{array}$ & $\pm \overline{7-10}$ & Moderate & *Slight 36 & $\underset{\mathbf{L V}}{\mathbf{N}}$ & $\stackrel{+}{++}$ & $\bar{t}$ & $\overline{-}$ & $\begin{array}{l}100 / 80 \\
125 / 90\end{array}$ & $\begin{array}{l}+(+) \\
+(+)\end{array}$ & $\overline{+}$ & \pm & $\overline{++}$ & & $\overline{35}$ & $\begin{array}{l}\mathrm{V} \\
\mathrm{v}\end{array}$ \\
\hline $\begin{array}{l}6 \\
7\end{array}$ & $\begin{array}{l}12 \mathrm{M} \\
37 \mathrm{~F}\end{array}$ & $\begin{array}{l}12 / 12 \\
15 / 12\end{array}$ & 二 & $\begin{array}{l}\text { So } \\
\text { Slight } \\
\text { Moderate } \\
\text { always }\end{array}$ & *Moderate & $\underset{\mathbf{L V}}{\mathbf{N}}$ & + & $=$ & $\mathbf{N}$ & $\begin{array}{r}80 / 65 \\
115 / 95\end{array}$ & $\stackrel{+(+)}{+}$ & $\stackrel{(+)}{++}$ & $=$ & $\bar{t}$ & $\begin{array}{l}\text { Vertical } \\
\text { Trans- } \\
\text { verse }\end{array}$ & 37 & $\stackrel{S}{\mathbf{S}}$ \\
\hline 8 & $3 \mathrm{~F}$ & $20 / 12$ & - & always & - & $\mathbf{N}$ & + & - & $\mathbf{N}$ & - & + and & - & - & - & $\begin{array}{l}\text { verse } \\
\text { Vertical }\end{array}$ & - & $\mathbf{S}$ \\
\hline $\begin{array}{r}9 \\
10\end{array}$ & $\begin{array}{l}6 \mathrm{M} \\
9 \mathrm{M}\end{array}$ & $\begin{array}{l}24 / 12 \\
24 / 12\end{array}$ & $=$ & $=$ & 二 & $\stackrel{\text { LV }}{\mathbf{N}}$ & $\begin{array}{l}++ \\
++\end{array}$ & \pm & $\left(\frac{-}{\mathbf{N}}\right)$ & $\begin{array}{l}95 / 70 \\
105 / 65\end{array}$ & $\stackrel{+}{ \pm}$ & $=$ & $=$ & 二 & & $\begin{array}{l}6 \\
9\end{array}$ & $\begin{array}{l}\mathrm{V} \\
\mathbf{S}\end{array}$ \\
\hline $\begin{array}{l}11 \\
12\end{array}$ & $\begin{array}{r}9 \mathbf{M} \\
19 \mathbf{M}\end{array}$ & ${ }_{3}^{30 / 12}$ & $\overline{ \pm 5}$ & Slight & $=$ & $\begin{array}{l}\mathrm{LV} \\
\mathbf{L V}\end{array}$ & $\stackrel{++}{+}$ & 二 & $\stackrel{+}{N}$ & $\begin{array}{l}100 / 85 \\
130 / 85\end{array}$ & + & $\stackrel{+}{+}$ & ++ & $=$ & & $\overline{16}$ & $\begin{array}{l}\mathbf{S} \\
\mathbf{S}\end{array}$ \\
\hline 13 & $6 \mathrm{M}$ & 3 & - & - & - & $\mathbf{N}$ & + & + & $\mathbf{N}$ & $110 / 70$ & $(+)$ & - & - & - & & 6 & v \\
\hline $\begin{array}{l}14 \\
15\end{array}$ & $\begin{array}{l}9 \mathrm{M} \\
\mathbf{M}\end{array}$ & $\begin{array}{l}3 \\
3\end{array}$ & $=$ & $=$ & 二 & $\stackrel{\mathbf{N}}{\mathbf{N}}$ & $\stackrel{+}{+}$ & $\overline{+}$ & $\stackrel{\mathbf{N}}{\mathbf{N}}$ & $\begin{array}{l}90 / 70 \\
95 / 70\end{array}$ & + & $\stackrel{(+)}{+}$ & $=$ & 二 & & $\bar{z}$ & $\begin{array}{l}\mathbf{S} \\
\mathrm{V}\end{array}$ \\
\hline $\begin{array}{l}16 \\
17 \\
18\end{array}$ & $\begin{array}{r}5 \mathrm{M} \\
7 \mathrm{M} \\
34 \mathrm{~F}\end{array}$ & $\begin{array}{l}3 \\
4 \\
4\end{array}$ & $\overline{\overline{+7}}$ & $\begin{array}{l}\text { Slight } \\
\text { Slight } \\
\text { Moderate } \\
30\end{array}$ & $\bar{z}$ & $\underset{\mathbf{L V}}{\mathbf{N}}$ & $\begin{array}{c}++ \\
++ \\
+++\end{array}$ & = & $\begin{array}{l}\mathbf{N} \\
(-) \\
(-)\end{array}$ & $\begin{array}{r}95 / 65 \\
105 / 70 \\
105 / 80\end{array}$ & $\begin{array}{c}+ \\
+ \\
+\end{array}$ & $\bar{E}$ & $=$ & 三 & & $\begin{array}{l}7 \\
32\end{array}$ & \\
\hline 19 & $38 \mathrm{~F}$ & 5 & - & Moderate & *- & LV & ++ & - & - & $100 / 80$ & $(+)$ & + & - & - & & 25 & $\mathbf{v}$ \\
\hline 20 & $24 \mathrm{~F}$ & 5 & - & ${ }^{14}-$ & - & $\mathbf{N}$ & ++ & + & + & $100 / 80$ & $(+)$ & $(+)$ & $(+)$ & - & & 24 & $\mathbf{v}$ \\
\hline $\begin{array}{l}21 \\
22\end{array}$ & $\begin{array}{r}9 \mathrm{~F} \\
8 \mathrm{~F} \\
7 \mathrm{M} \\
18 \mathrm{M}\end{array}$ & $\begin{array}{l}6 \\
7 \\
7 \\
8\end{array}$ & 二 & $\begin{array}{l}\text { Slight } \\
\text { Slight } \\
\text { Stiont } \\
16\end{array}$ & $=$ & $\begin{array}{l}\mathrm{LV} \\
\mathrm{LV} \\
\mathrm{LV}\end{array}$ & $\begin{array}{c}++ \\
++ \\
++\end{array}$ & $\frac{ \pm}{ \pm}$ & $\begin{array}{l}(-) \\
(-) \\
(-)\end{array}$ & $\begin{array}{l}100 / 85 \\
105 / 90 \\
105 / 65 \\
155 / 120\end{array}$ & $\begin{array}{c}+ \\
++ \\
+\end{array}$ & $\begin{array}{l}(+) \\
(+) \\
(+)\end{array}$ & $\frac{(+)}{t}$ & $\bar{z}$ & & $\begin{array}{l}7 \\
7 \\
\end{array}$ & \\
\hline & $18 \mathrm{M}$ & 8 & \pm 14 & Slight 16 & Slight & $\mathbf{N}$ & ++ & + & + & $155 / 120$ & + & & + & - & & - & \\
\hline 25 & $50 \mathrm{M}$ & 8 & - & Slight & - & $\mathbf{L V}$ & +++ & ++ & $(-)$ & $120 / 80$ & + & +++ & ++- & +++ & & 39 & v \\
\hline $\begin{array}{l}26 \\
27\end{array}$ & $\begin{array}{l}23 \mathrm{M} \\
35 \mathrm{M}\end{array}$ & 9 & 二 & $\begin{array}{l}\text { Slight } \\
\text { Moderate } \\
34\end{array}$ & $\stackrel{\text { Slight } 22}{*-}$ & $\mathbf{L V}$ & $+\stackrel{+}{++}$ & \pm & $\stackrel{(-)}{N}$ & $\begin{array}{l}100 / 60 \\
130 / 90\end{array}$ & $\stackrel{+}{++}$ & $\overline{+}$ & \pm & $\stackrel{++}{(+)}$ & & L $\stackrel{22}{\mathrm{BBBl}}$ & $\mathrm{v}$ \\
\hline $\begin{array}{l}28 \\
29 \\
30\end{array}$ & $\begin{array}{lll}29 & \mathrm{M} \\
29 & \mathrm{M} \\
32 & \mathrm{M}\end{array}$ & $\begin{array}{r}9 \\
10 \\
10\end{array}$ & $\underline{+9}$ & $\begin{array}{l}\text { Slight } 17 \\
\text { Slight } 16 \\
\text { Worse }\end{array}$ & $\begin{array}{l}\text { *Slight } 17 \\
\text { Slight } 16\end{array}$ & $\begin{array}{l}\mathrm{LV} \\
\mathbf{L V} \\
\mathbf{N}\end{array}$ & $\begin{array}{l}++ \\
+ \\
++\end{array}$ & \pm & $\mid \begin{array}{l}\mathbf{N} \\
+ \\
(-)\end{array}$ & $\begin{array}{l}135 / 115 \\
135 / 75 \\
110 / 90\end{array}$ & $\begin{array}{l}(+) \\
++ \\
+\end{array}$ & $\underset{+}{+}$ & \pm & $\begin{array}{l}+ \\
+ \\
+\end{array}$ & & $\begin{array}{l}29 \\
28 \\
28\end{array}$ & \\
\hline 31 & $12 \mathrm{M}$ & 10 & - & & - & $\mathbf{N}$ & ++ & + & - & $105 / 65$ & - & + & - & - & & - & \\
\hline 32 & $48 M$ & 10 & - & Severe 46 & *Severe 46 & LV & ++ & - & $(-)$ & $105 / 85$ & ++ & + & + & + & & 40 & $v_{t}$ \\
\hline 34 & $\begin{array}{l}13 \mathrm{M} \\
15 \mathrm{M}\end{array}$ & $\begin{array}{l}12 \\
13\end{array}$ & $=$ & $\begin{array}{l}\text { Slight } \\
\text { Slight }\end{array}$ & Slight 13 & $\stackrel{\mathbf{N}}{\mathbf{N}}$ & ++ & $\stackrel{+}{++}$ & $\begin{array}{l}\mathbf{N} \\
\mathbf{N}\end{array}$ & $\begin{array}{l}110 / 80 \\
105 / 85\end{array}$ & $\stackrel{++}{+}$ & $\stackrel{(+)}{+}$ & + & 二 & & 二 & $\mathrm{v}$ \\
\hline 35 & $17 \mathrm{M}$ & 15 & - & - & - & $\mathbf{N}$ & ++ & - & $\mathbf{N}$ & $120 / 85$ & + & + & + & - & & - & 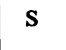 \\
\hline 36 & $25 \mathrm{M}$ & 18 & - & Slight & - & LV & ++ & ++ & $(-)$ & $145 / 110$ & +++ & ++ & + & - & & 25 & $V^{*}$ \\
\hline 37 & $49 \mathrm{M}$ & 19 & - & $\begin{array}{l}\text { Slight } 27 \\
\text { Severe 48 }\end{array}$ & - & LV & ++ & - & + & $110 / 90$ & +++ & + & $(+)$ & - & $\begin{array}{l}\text { Trans } \\
\text { verse } \\
\text { verse }\end{array}$ & 49 & $\mathbf{v}$ \\
\hline 38 & $40 M$ & 37 & - & Severe 38 & ${ }_{38}^{*}$ Moderate & $\mathbf{L V}$ & + & ++ & $(-)$ & $120 / 65$ & + & + & + & ++ & Vertical & $\mid$\begin{tabular}{|l} 
R \\
$\mathbf{3 9}$
\end{tabular} & $\mathrm{V}^{*}$ \\
\hline 39 & $42 M$ & 39 & - & ${ }_{40}^{\text {Moderate }}$ & Slight & LV & + & $(+)$ & $\mathbf{N}$ & $115 / 95$ & ++ & + & - & + & & - & v \\
\hline 40 & $42 M$ & 42 & - & & - & $\mathbf{N}$ & ++ & - & $\mathbf{N}$ & $140 / 90$ & $(+)$ & + & + & - & $\begin{array}{c}\text { Trans- } \\
\text { verse }\end{array}$ & - & $\mathbf{S}$ \\
\hline
\end{tabular}

$\mathrm{N}=$ Normal. $\quad-=$ absent. $(-)=$ diminished. $\quad *$ =Effort syncope. A.2.=Aortic second sound. L.V.S. =Left ventricular strain. ${ }^{* *}=$ Subactue bacterial endocarditis. $t=$ Confirmed post mortem. $V=$ Valvular. $S=$ Subvalvular. 


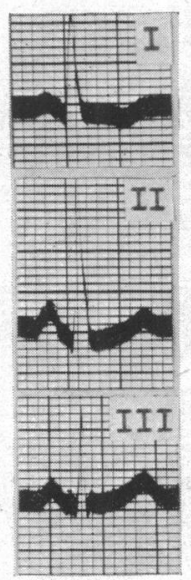

A

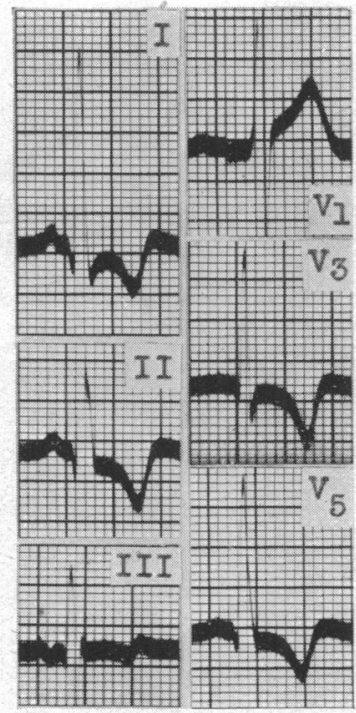

B

FIG. 9.-Electrocardiograms showing increasing left ventricular strain. (A) When aged 39 , with slight inversion of TI. (B) When aged 50, with deep inversion of S-TI and other signs of left ventricular strain. Case 25.

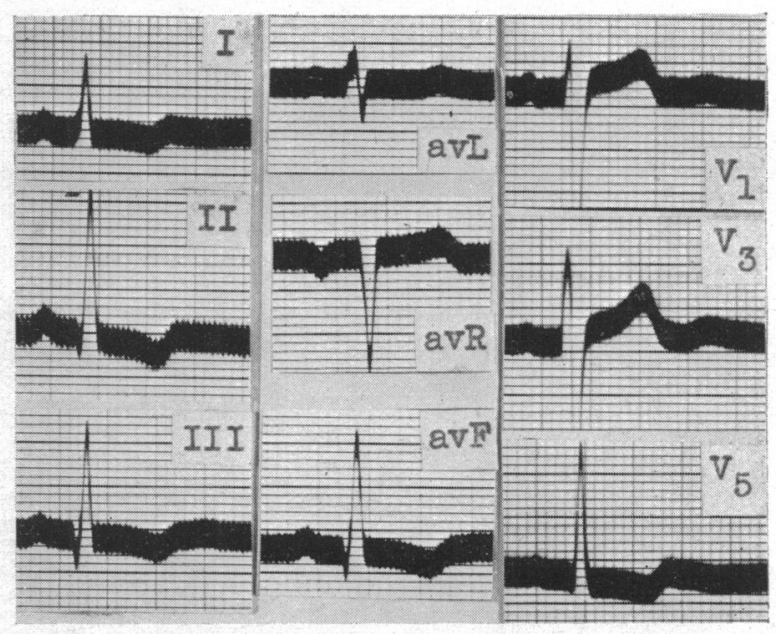

Fig. 10.-Electrocardiogram, showing the common combination of a vertical electrical axis with left ventricular strain. Case 29.

played some part. Conversely, in thirteen patients with a transverse electrical axis and left heart strain there was a clinically pure stenosis in eight.

A low $\mathrm{T}$ wave in aVF or aVL may be the first evidence of developing ventricular strain, either to be confirmed forthwith in V7 (Case 26) or to appear later in præcordial records. Left heart strain was occasionally seen without obvious fluoroscopic ventricular enlargement (Cases 2 and 10). Alternatively moderate left ventricular enlargement was present without cardiographic heart strain (Cases 33 and 39). Left bundle branch block occurred in Case 27, aged 35, and right bundle branch block in Case 38, aged 40.

\section{The Incidence of Valvular and Subvalvular Aortic Stenosis}

Congenital aortic stenosis has been regarded as rare (White, 1951) though Wood (1950) thought that subaortic stenosis was less rare and formed two per cent of his congenital cases. Congenital aortic stenosis is certainly not very rare, for among 460 acyanotic cases seen in 1947-51 there were 32 with aortic stenosis ( 7 per cent or nearly 3 per cent of all the congenital cases), and we think most of these had valvular stenosis.

In the 1000 cases analysed by Maud Abbott (1936) there were 18 with subaortic and 11 with valvular stenosis compared with 105 with coarctation of the aorta. There are relatively few postmortem reports of subvalvular stenosis, and Kiloh (1950) was able to find less than 40 cases in all. Necropsies of congenital valvular stenosis are equally uncommon, but we think this is because of its good prognosis and the difficulty of recognizing the congenital ætiology when the patient dies late in life. In our view congenital aortic stenosis is relatively common, and this is supported by the papers of Gallavardin (1936), Young (1944), and Kiloh (1950).

Brown (1950) thinks it difficult to differentiate valvular and subvalvular stenosis, but that those with valvular stenosis are more likely to have the typical pulse of aortic stenosis, a diminished or absent aortic second sound, and an aortic diastolic murmur, though this has been found with a a bicuspid valve and subaortic stenosis: they are also more likely to have calcification of the valves 
though subvalvular calcification has been reported. In both the enlargement of the left ventricle may be small and there may be some dilatation of the aorta and the electrocardiogram may be normal or may show left axis deviation. In both the symptoms may be slight and the lesion may be found at routine examination, but both are prone to the risk of bacterial endocarditis. His own experience of 43 cases suggested that the pulse is normal in about one-third of them. Wood (1950) thinks that patients with subaortic stenosis differ in having a clear second sound, a normal pulse, little enlargement of the left ventricle, and a good prognosis.

In our cases the allocation to the valvular as opposed to the subvalvular type has depended on the presence of visibly calcified valves, and to a lesser extent of an aortic diastolic murmur, and of an impaired second sound. On such a basis 31 cases were considered valvular and 9 subvalvular. The oldest patient, with the exception of one aged 42 (Case 40), who was thought to have subvalvular stenosis was 19 years of age (Case 12).

The quality of the pulse and its pressure merely indicate the severity of the lesion and may not help in differentiation unless we can assume that valvular stenosis is generally more severe than subvalvular: if so, the subvalvular stenoses are further reduced. The post-stenotic aortic dilatation is probably without value in differentiation.

\section{Prognosis}

In Abbott's series (1936) the average period of survival with aortic valvular stenosis was 3.75 and the maximum was 24 years, while with subaortic stenosis the figures were 22.6 and 58 years. Brown (1950) also thinks the prognosis much better in cases with subaortic stenosis, and Wood (1950) says that most patients with aortic valvular stenosis die young, but that there is a good prognosis in those with subaortic stenosis.

In our own experience the prognosis in valvular stenosis is good in children and few patients have severe symptoms till they reach adult or even middle age, when the outlook becomes more serious. Gallavardin (1936) emphasized the good prognosis of valvular stenosis, stating that few of his patients under 25 had any symptoms and that even between 25 and 50 only about half had severe symptoms. The absence of necropsies in the series of Gallavardin and Kiloh and ourselves, except for two patients of about $\mathbf{4 0}$ who died after aortic valvotomy, seems to confirm this view. We have, however, found two specimens in the Guy's Hospital Museum where children have died, one very suddenly and one with heart failure rather suddenly, as a result of congenital aortic stenosis. Dr. Keith Simpson informs us that among the 30,000 coroners' necropsies that he has performed he remembers about six with congenital aortic valvular stenosis in addition to these two reported in the next section, but can not remember any with subaortic stenosis: there have, of course, been many older patients with severe aortic stenosis, but they have been regarded as rheumatic or atherosclerotic, though he has been much impressed by the large proportion without mitral stenosis.

We must, therefore, modify the view that the prognosis is always good by realizing that occasionally the stenosis is so severe that death may follow early.

\section{CASES WITH NeCROPSY}

We shall describe shortly the clinical and post-mortem findings in these two patients and in the two of our series who died after aortic valvotomy. The fusion of the valves and their irregularity in the two younger are more in keeping with a congenital than an inflammatory origin. In the older two the degree of secondary change and of calcification makes a decision more difficult, but one of them appeared to have a bicuspid valve and we think the balance of evidence is that here, too, the original lesion was congenital.

Case 32. This man knew that he had a murmur since childhood; he had never had rheumatic fever. He had no symptoms until 1944, when at the age of 40 , he had severe dyspnœa and sternal pain after running in the Home Guard. There was a rough systolic murmur and thrill over the sternum: the heart was of normal size and the blood pressure 120/80. There was left axis deviation and TI was slightly inverted. He was thought to have slight pulmonary stenosis. Two years later he saw Dr. Bramwell and Dr. Towers 
who found the same signs and diagnosed aortic stenosis: his pain in the chest, which was now more frequent and more easily provoked, was accepted as anginal.

He was first seen by us in 1952, aged 48, because during the previous year walking even 25 yards provoked sternal pain and dyspnœea, though afterwards he could walk up to a quarter of a mile slowly. There was a rough systolic murmur and thrill maximal in the mid-line at the base; no diastolic murmur was heard. The blood pressure was now 105/85. The maximum transverse diameter of the heart increased to $15 \cdot 0$ from $13.7 \mathrm{~cm}$. in 1947 (c.t.r. 54 from $49 \%$ ). On screening, the left ventricle was enlarged, but there was nothing to suggest mitral stenosis: the first part of the aorta was somewhat dilated and pulsated freely, and calcification of the aortic valves was easily seen. His cardiogram showed left ventricular preponderance with deeper inversion of TI.

The diagnosis made was pure aortic stenosis, probably congenital, and an operation was advised in view of his severe disability and deterioration. He was admitted to hospital within two months, but had developed congestive heart failure. At cardiac catheterization the pressure in the brachial artery was wider than the clinical estimate, i.e. $112 / 60 \mathrm{~mm}$. and in the pulmonary trunk 70/35; the pressure in the right atrium, 27/14, was also raised. The cardiac output was 3.4 litres a minute and hardly changed with exercise. His failure improved but did not disappear with treatment and there was still some pericardial effusion.

At operation the pressure was 216/36 in the left ventricle against 112/76 in the aorta. Mr. Brock was able to increase the aortic opening and his condition was satisfactory for some hours, but signs of left ventricular failure increased, and he died that night.

Necropsy. The left ventricle was much hypertrophied. The pulmonary and tricuspid valves were normal. The mitral orifice was normal and the valve was normal except for heavy calcification spreading from the aortic valve over the base of the aortic cusp. The coronary orifices and arteries were normal, and the aorta showed no general atheroma: there were nutmeg changes in the liver, which was slightly cirrhotic.

The appearance of the aortic valve is shown in Fig. 11: there was a very small irregular central opening about 4 by $1 \mathrm{~mm}$., which had been split at operation to the periphery on one side, but not on the other, making a total length of $12 \mathrm{~mm}$. There was severe, craggy calcification of the cusps, and the only part that might have been fairly mobile was to either side of the split. It was not easy to be certain about the commissures, but the valve seemed bicuspid with only two sinuses, though about the middle of the slightly larger sinus there might have been the remnant of another commissure.

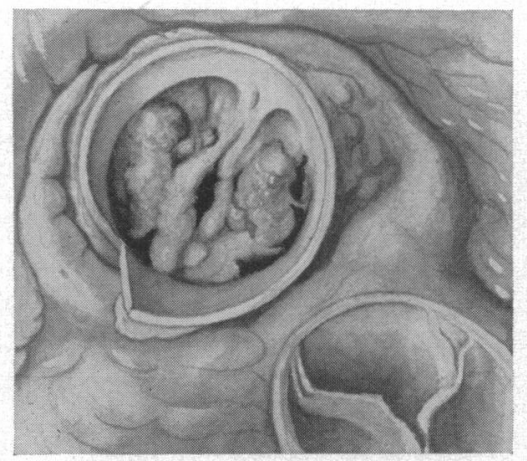

FIG. 11.-The aortic valve viewed from above, from a man, aged 48 , who died after aortic valvotomy. Gross craggy calcification of a valve that was probably bicuspid. At operation there was only a small central opening which was successfully split to the posterior border, but not anteriorly because of the gross calcification. Case 32.

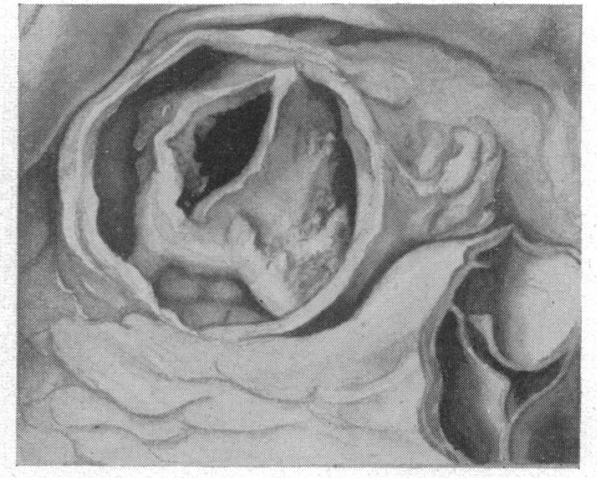

FIG. 12.-The aortic valve from above, from a man, aged 50, who died after aortic valvotomy. The valve was probably tricuspid, but is fibrous and calcified. The original opening was thought to be small and central, but here it has been opened to its maximum capacity after being split at operation. Case 37.

Case 37. This man had no history of rheumatic fever but was always rather breathless playing games and was told there was a murmur at a routine examination when he was 19 and again 8 years later when he had pneumonia; the blood pressure was then 110/80. After this he was a little breathless, but worked as a 
male nurse until 1950, when he was 48. The lesion was then recognized as pure aortic stenosis, and though he was given easier work he continued to lose ground.

He was first seen by us when he was 49 years old. The distance he could walk had fallen from two miles to half a mile, and stairs had become difficult. There was a rough systolic murmur and thrill in the aortic area, and a slow rising anacrotic pulse with a blood pressure of about $102 / 85$. No diastolic murmur was heard. The heart was a little enlarged, and on screening this was shown to be due to the left ventricle; the first part of the aorta was prominent and pulsatile. The cardiogram showed left ventricular preponderance with some inversion of $\mathrm{T}$ in leads I and V5.

During the next six months he found he could not manage the light work he had done before, and became anxious for aortic valvotomy. The heart was larger, c.t.r. $58(17 \cdot 5 / 30)$, but decreased after treatment to 53 per cent $(16 / 30 \mathrm{~cm}$.). The liver was enlarged and tender and there was a small effusion at the right base which cleared up with rest, digoxin, and a low salt diet. A direct reading of the pressure in the brachial artery was $96 / 60$, and in the pulmonary trunk $32 / 14$.

At operation on $23 / 10 / 52$ the pressure was $172 / 8 \mathrm{~mm}$. $\mathrm{Hg}$ in the left ventricle and about $70 / 50 \mathrm{~mm}$. in the aorta. Mr. Brock was reasonably satisfied with the increase in the size of the valve opening, but ventricular fibrillation started during the operation, and though it was stopped with the defibrillator, the blood pressure remained below 70 and the pulse rate rose from 110 to 140 . He developed signs of pulmonary œdema, and died the next morning.

Necropsy. The left ventricle was much hypertrophied with some subendocardial fibrosis, and there seemed to be some hypertrophy of the right ventricle as well. The aorta was normal except that it seemed constricted where it was joined by the commissures, the sinuses of Valsalva being deeper than usual, and it was a good deal dilated beyond this.

There was severe stenosis of the aortic valve from fusion of the three cusps with much thickening and calcification (Fig. 12). The orifice was oval and, after valvotomy, measured about 13 by $5 \mathrm{~mm}$. between the posterior and left anterior cusps. The heart showed no other abnormalities.

Guy's Hospital Museum Specimen 2309. This girl, aged 15, had been under medical care for some 10 years since her congenital heart disease had been recognized. She complained of tiredness while out one day and went to bed. Two days later a doctor was called and found some congestion of the lungs and œedema of the legs: a high-pitched systolic murmur was heard in the aortic area and up the neck. The next morning she was found dead in bed.

Necropsy. There were general signs of congestive heart failure, but no other abnormality was found outside the heart. The valves were normal, except for the aortic. It was difficult to say how many cusps there had been as the valve appeared like a continuous thickened diaphragm projecting as a cone into the aorta, but it seemed more likely to have been bicuspid. The orifice measured 6 by $3 \mathrm{~mm}$. and was made rigid by great thickening and rolling of its edges. The cusps were thickened in most parts, though there was one translucent area in what appeared to be the largest cusp, the furthest away from the pulmonary opening (Fig. 13). There was no obvious calcification. The aorta was hypoplastic, and smaller than the pulmonary trunk, about $13 \mathrm{~mm}$. against $18 \mathrm{~mm}$. There was gross concentric hypertrophy of the left ventricle and also some of the right ventricle presumably because a failing left ventricle had transmitted the increased pressure to the right side of the heart: if so, it is surprising that there was not a longer history of increasing dyspnœa, but the history available was not detailed. The heart weighed $765 \mathrm{~g}$.- an enormous heart for a girl of this age.

Guy's Hospital Museum Specimen 2308. This boy, aged 11, collapsed and died while playing with other boys at home. He was of normal build, but had been somewhat short of breath and had been under medical supervision at school for congenital heart disease. There were said to be high-pitched systolic and diastolic murmurs in the aortic area; he was not greatly disabled and was able to attend school normally.

Necropsy. No abnormality was found outside the heart. The mitral valve was normal and so was the rest of the heart except the aortic valve and the left ventricle. The heart weighed $340 \mathrm{~g}$. There was concentric hypertrophy of the left ventricle and some scarring of its muscle due to the edge of the valve turning over the orifice of the left coronary artery. The aortic cusps were difficult to distinguish and the valve was a conical shape and consisted of thickened connective tissue covered by smooth endothelium, rising to a small orifice towards the upper left-hand margin of the valve (Fig. 14). This opening was no more than 3 by $2 \mathrm{~mm}$., and it seemed difficult to think that it could ever have been central. Looked at from below, the valve was even more conical, with the opening at the top, but asymmetrical. The greater part of the valve cusps were hard and nodular, but did not appear to be calcified. The aorta was small, $10 \mathrm{~mm}$. in diameter. 


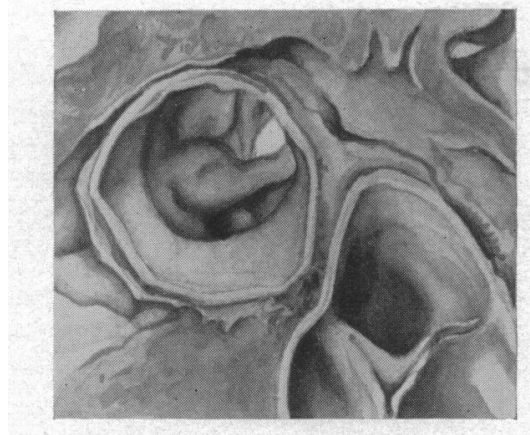

FIG. 13.-The aortic valve from above, from a girl of 15 who developed congestive failure and died suddenly a few days later. The cusps are grossly abnormal and fused; there were probably two only, but it is difficult to be sure of this. The small opening is eccentric and somewhat posterior and to the left. The pulmonary trunk was larger than the aorta. Case No. 2309.

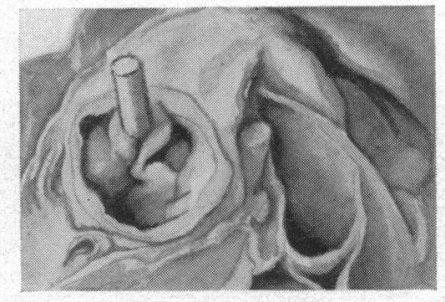

FIG. 14.-The aortic valve from above, from a boy, aged 11, who died suddenly. The cusps were completely fused so that the number cannot be recognized and the valve was very irregular and funnel-shaped. The opening could hardly be seen, so a probe has been passed through it. It was eccentric, being rather posterior and to the left. Case No. 2308.

\section{Discussion OF ÆTIOLOGY}

Monckeberg (1904) assigned aortic stenosis to acute endocarditis or slowly developing valvular sclerosis. This dual ætiology, infective and degenerative, attracted equal support until the publication of Karsner and Koletsky's (1947) monograph in which evidence of rheumatic infection was found in no less than 196 of 200 patients with aortic stenosis: there were two examples of congenital bicuspid aortic valves with marked stenosis, showing the congenital ridge, neither of which revealed rheumatism histologically. Previously Sophian (1945) had remarked that histologically rheumatism was so frequent that its presence did not prove that the ætiology was rheumatic. There must always be great difficulty in evaluating the previous disease process represented in scarred and calcareous aortic valves; evidence of rheumatic infection elsewhere in the heart may not be decisive and must be assessed in the knowledge of the natural history of the disease and of the case: otherwise the discipline of histology becomes tyrannical rather than salutary. Karsner and Koletsky (1947) suggest that only with rare exceptions is calcific disease of the aortic valve not due to rheumatism. It is peculiar that in their series no less than 26 per cent of the hearts were essentially normal in weight, and we think that many of these were much more likely to be congenital.

The natural history of rheumatic fever is that of recurrent infection culminating in failure of the myocardium. The aortic valves may be affected alone, but then pure aortic stenosis is relatively rare (Campbell and Shackle, 1933). Most often there is gradual progression from aortic incompetence to some degree of aortic stenosis, which may remain unimportant or become severe. With congenital aortic stenosis, however, there is no impairment in the constitution, repeated cardiac failure does not occur, the incompetence comes after the stenosis, if at all, and the stenosis is often gross at an age when with rheumatism this would be improbable. This is not to state that a pure stenosis cannot be rheumatic, but under the age of thirty it is more likely to be congenital.

Marvin and Sullivan (1935) discussing the ætiology of aortic stenosis said that they referred to it as atherosclerotic because it seemed that the signs and symptoms were not due to the original lesion, but rather to the calcareous changes that occurred only after the passage of many years.

Gallavardin (1909, 1921, and 1936) first emphasized the frequency of a type of aortic stenosis that was not rheumatic " qui se caractérise par sa tendance particulière á réaliser le retrécissement aortique pur et que cette cause doit-être recherchée en dehors des atteintes rhumatismales franches ou frustes." In 1936 he described 50 cases that closely resemble those we have described: half of them were under 25 and half between 25 and 50, cases older than this being excluded. All were 
thought to have aortic stenosis, but less than half seem to have had a striking thrill. Over onethird had an aortic diastolic murmur, but it was never loud. The pulse was never water-hammer; it was sometimes normal or small and often showed the features of aortic stenosis. Nearly fourfifths of the patients were men. A few had angina or syncope on effort. He gave good reasons for thinking the patients were not rheumatic, but did not accept them as congenital. He thought that there might have been an endocarditis of unknown origin in fotal life, and drew an analogy with cases of pulmonary valvular stenosis, but this is now widely accepted as a true congenital lesion and not due to inflammatory changes before birth: we think that this is also true of the cases of aortic stenosis.

Young (1944), reporting 12 cases that were found in soldiers between 19 and 30 years of age who were free from symptoms, thought that these were subaortic stenosis, presumably only because he thought the prognosis better in this group. Kiloh (1950) describes his findings in 26 cases of pure aortic stenosis, those over 50 being excluded. He agreed with Gallavardin's view that they were not rheumatic, but thought there was no final answer to the ætiology without necropsy evidence. In many of his cases, as in Gallavardin's, the signs were found at routine examination. He found, generally, slight enlargement of the left ventricle on radioscopy, and more frequently, dilatation of the first part of the aorta, which he thought particularly important for diagnosis in these young patients without hypertension Calcification of the aortic valves was seen in half his cases

From consideration of the present material we think the atiology of aortic valvular stenosis may be more accurately assessed from the history, progress, and physical signs than from autopsy material, and that by analogy the diagnosis of congenital heart disease may be made initially in adult life. Ideally, the lesion should have been recognized prior to the age of four, and this applied to nearly half the patients of the present series. But the valvular lesion is progressive and symptoms are late in appearance, so that early diagnosis is generally made only at a routine medical examination, when there may be confusion as to the nature of the congenital lesion.

\section{A Note on Arterial Dilatation Beyond a Constriction}

The nature of the arterial dilatation beyond an aortic or pulmonary valvular stenosis has aroused much interest. Chevers (1842) referred to the thinning and dilatation of the first part of the aorta with valvular stenosis and attributed it to "the long continuance of a degree of stagnation in the contents of the tube," or, alternatively, to the fixed valves remaining rigid in diastole, thereby causing the whole weight of the blood to impinge upon the sides of the aorta. This dilatation distal to a constriction is not easy to understand, but Professor G. Stead has given us a physical explanation based on Bernouilli's principle that, when a liquid flows through a tube that is not uniform in diameter, pressure on the walls is greatest when the velocity is least. If a liquid is flowing through a tube the velocity $(v)$ must be increased (to $V$ ) when it is flowing through the narrow part. A mass $(m)$ of liquid will therefore gain momentum when it enters the constriction and lose it again when it emerges. The loss of momentum $(m V-m v)$ after passing the constriction must be brought about by an opposing (or braking) force acting in the opposite direction to the flow, and thus the pressure must be higher on the far side of the constriction. For the same reason it is higher on the proximal side, but this does not imply that it must be the same on both sides because, owing to the viscosity of the blood, the difficulty of forcing it through the constriction will lead to a lower pressure on the distal side. The very low pressure often observed beyond pulmonary valvular stenosis makes this explanation more difficult for pulmonary than for aortic stenosis. In the instance in question this higher pressure and turbulence beyond the constriction will lead to a dilatation of the aorta, while on the proximal side the pressure is taken by the hypertrophied ventricular muscle.

This conception of a pressure higher beyond than within a constriction is not easy to understand in that blood appears to be flowing from a level of low pressure to a level of high pressure, but these principles of hydrodynamics provide some explanation, and post-stenotic turbulence may be another factor. Perhaps the way a river widens and its banks fall away below a constriction, such as a weir, is an analogy that makes it easier to understand. 


\section{SUMmaRY AND CONCLUSIONS}

Congenital aortic stenosis, especially valvular stenosis, is not uncommon. It may pass unrecognized for many years or even till the stenosis is made more severe by the addition of fibrosis and calcification. We think that the aortic stenosis of many patients presenting in middle life is often congenital in origin.

We have described 40 cases of congenital aortic stenosis in nearly half of which the murmur was heard before they were four years old, and have discussed the implications of the history and clinical findings. We have described the necropsy findings in two of these, and in two other children.

The main points in the diagnosis are the recognition of heart disease early in life without a history of acute rheumatism; the systolic murmur and thrill of aortic stenosis without evidence of mitral stenosis; a heart that is not much enlarged, often with the minor enlargement of the left ventricle persisting with little change over the years, even when there are cardiographic signs of left ventricular strain; and some prominence of the first part of the aorta, best seen in the left anterior oblique position. This dilatation and pulsation of the first part of the aorta are helpful in the diagnosis, with the clinical background. The combination of a vertical electrical axis with left ventricular preponderance and often strain, in the absence of mitral stenosis, is suggestive of congenital aortic stenosis.

In the more severe cases, but not in the others, there will be a small, slow-rising pulse and a low pulse pressure. Later, there may be aortic incompetence, but it is generally slight. The aortic second sound is diminished in about half the cases. Calcification of the aortic valves was seen once before the age of 20 , was common after 30 , and was the usual finding after 40 years of age.

Generally, dyspnœa is slight or even absent, and there are few symptoms until 25 or 30 years of age or even later. Except in the most severe cases, the prognosis is good, at least until middle age. Serious symptoms are often absent until calcification and sclerosis make the stenosis more severe.

The evidence we have brought forward for this picture of congenital aortic stenosis is mainly clinical. We think that the pathological basis for the ætiological diagnosis of aortic stenosis needs reconsideration in the light of these views.

We are grateful to Mr. R. C. Brock for the notes about the findings at operation in Cases 32 and 37, and to Dr. H. E. Holling for the pressure readings in these patients. We should like to thank Miss M. Waldron for the drawings of the aortic valves, and Mr. C. Engle for the photography.

\section{REFERENCES}

Abbott, M. E. (1936). Atlas of Congenital Cardiac Disease. New York.

Bonetus, T. (1679). Sepulchretum sive anatomia practica ex cadaveribus morbo denatis. Geneva,1679. Vol. 1, book 2. Observatio XXVI, p. 891 in the edition of 1700.

Brown J. W. (1950). Congenital Heart Disease. 2nd ed., Staples Press, London.

Campbell, J. M. H., and Shackle, J. W. (1933). Guy's Hosp. Rep., 83, 168.

Chevers, N. (1842). Guy's Hosp. Rep., 7, 387.

Davies, C. E., and Steiner, R. E. (1949). Brit. Heart J., 11, 126.

Gallavardin, L. (1909). Lyon Méd., 112, 189.

- (1921). Presse. Méd., 29, 224.

- (1936). J. Méd. Lyon, 17, 593.

Gibbs, A. J. (1935). Guy's Hosp. Rep., 85, 275.

Karsner, H. T., and Koletsky, S. (1947). Calcific Disease of the Aortic Valve. Philadelphia.

Keith, Sir A. (1924). Lancet, 2, 1267.

Kiloh, G. A. (1950). Brit. Heart J., $12,33$.

Koletsky, S. (1941). Arch. intern. Med., 67, 129.

Marvin, H. M., and Sullivan, A. G. (1935). Amer. Heart J., 10, 705.

Mönckeberg, J. G. (1904). Virchows Arch. path. Anat., 176, 472.

Shennan, T. (1905). Lancet, 1, 21.

Smart, A. (1904). Lancet, 2, 1417.

Sophian, L. H. (1945). Amer. J. med. Sci., $210,644$.

White, P. D. (1951). Heart Disease. 4th ed., The Macmillan Co., New York, p. 687.

Wiggers, C. J. (1935). Physiology in Health and Disease. London.

Wood, P. (1950). Diseases of the Heart and Circulation. Eyre and Spottiswoode, London.

Young, D. (1944). Amer. Heart J., 28, 440. 